\title{
Floral Characteristics Analysis of Plants in Tianjin Lingang Urban Ecological Wetland Park
}

\author{
Y Y Wan ${ }^{1, a}, \mathrm{H} Y \mathrm{Li}^{1, \mathrm{~b}}, \mathrm{M} X \mathrm{He}^{1, \mathrm{c}}, \mathrm{N} \mathrm{Zhao}^{1 \mathrm{~d}}, \mathrm{Q}$ zhang $^{1 \mathrm{e}}$ \\ ${ }^{1}$ College of Environmental Science and Engineering, Nankai University, Tianjin 300071,China

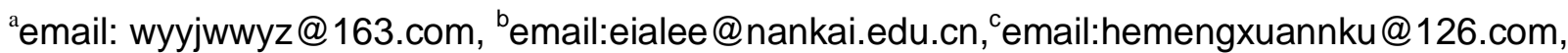 \\ demail:nku_zhaona@126.com, ${ }^{\mathrm{e}}$ zhangqian921204@163.com
}

\begin{abstract}
Keywords:Tianjin;Folra characteristics;Floristic geographical elements;Urban wetland park Abstract. This study aims to identify the composition and distribution characteristics of plant flora of Urban Ecological Wetland Park in Tianjin Lingang. Results show that plant species of Wetland Park in Tianjin Lingang are relatively rich.There are 246 vascular plants from 171 genera and 73 families. 16 families,37 genera gymnosperm species including 2 families and 5 genera Pinopsida and 1 families, 1 genera Ginkgopsida, recorded a total of 134 genera of dicotyledonous plants belonging to 57 families and 31 genera of monocotyledonous plants belonging to 13 families. The major families are Gramineae, Rosaceae and Asteraceae and the major genera is Chenopodium and Salix. From the point of Genera composition, small generas and monotypic generas account for higher proportion. 77 species of wild plants are mainly come from herbaceous plants, and the arbor layer is mainly composed of cultivated species. The flora of Wetland's vegetation in Lingang Ecological Wetlands Park had a wide distribution including 15 geographical components with 9 sub-types, $34.16 \%$ of the species are of the North temperate type, generally with a typical temperate floristic characteristics.
\end{abstract}

\section{Introduction}

Flora is a region (a certain period of time or a classification group) of all plants of sum owing to the comprehensive effects of the natural geographical environment,especially the natural and historical conditions, a results after evolution, a important basis of plant classification and a reaction of natural geographic environment ${ }^{[1-3]}$. In recent years, Urban Wetland Park is a big concern, research focuses on the plant characteristics ${ }^{[4-6]}$, development status,sewage treatment technology, selection and arrangement of vegetation,but the research on the geographical areal-types of seed plants in urban wetland park is less. This study on flora analysis of plants for urban wetland park in order to provide reference advice about achieving a reasonable selection of plant species, and give the scientific community to configure and to improve the eco-system functions.

\section{Research method}

\section{Research area}

Lingang Ecological Wetland Park is an urban ecological wetland park with the advantages of water treatment and landscape effect combined, located in Tianjin Lingang industrial zone, east Bohai ten road, South to Binjiang Road, west Binhai Avenue, north up Changjiang Road, covering an area of about $63 \mathrm{hm}^{2}$. The overall shape of the park is looked like butterfly-shaped and there are three main major scenery plots including Subsurface Flow Constructed Wetlands, Adjusting Lake and Main Landscape in it. The typical park is built on the Bohai Bay muddy tidal flat, which had accumulated a considerable degree of pollution due to the long-term development of the coastal zone. Plants are sparse in the marsh along the coast which has been dehydrated and there has a big intensive distribution of Spartina Anglica community and halophytes.Effective collection of sewage and rainwater through the construction of artificial wetland,combined with water purification and recycling by international advanced ecological technology in wastewater treatment helped the wetland park achieve partial sewage zero emissions ${ }^{[7-8]}$. 


\section{Research method}

Vegetation surveys had been carried out all around the entire Lingang Urban Ecological Wetland $\begin{array}{lllll}\text { Park from } & \text { November } 2013 \text { to }\end{array}$ using field investigation and quadrat method.Recorded the community's species, location, data of elevation,plant arrangement, composition qualities and coverage has also been surveyed. Data analysis mainly uses the Excel form 2011 and the R 3.3.0 software.

\section{Result and analysis}

\section{Flora composition}

There are 246 vascular plants from 171 genera and 73 families. 16 families, 37 genera gymnosperm species including 2 families and 5 genera Pinopsida and 1 families, 1 genera Ginkgopsida, recorded a total of 134 genera of dicotyledonous plants belonging to 57 families and 31 genera of monocotyledonous plants belonging to 13 families.Results displayed that dicotyledonous plant occupies important position.Plant composition had a trend of centralization to some big typical world family,such as $\operatorname{Rosaceae}(28$ species),Compositae(25 species),Gramineae(17 species),Leguminosae(14 species) and Oleaceae(10 species), while also has tendency of moving upwards small generas and monotypic generas,such as Chenopodium and Salix.The composition of 47 monotypic family and 137 monotypic species were fully reflected the transitional and complexity of the wetland park, these kinds of plants from monotypic family or a monotypic species of plant are often appeared as a companion plant.

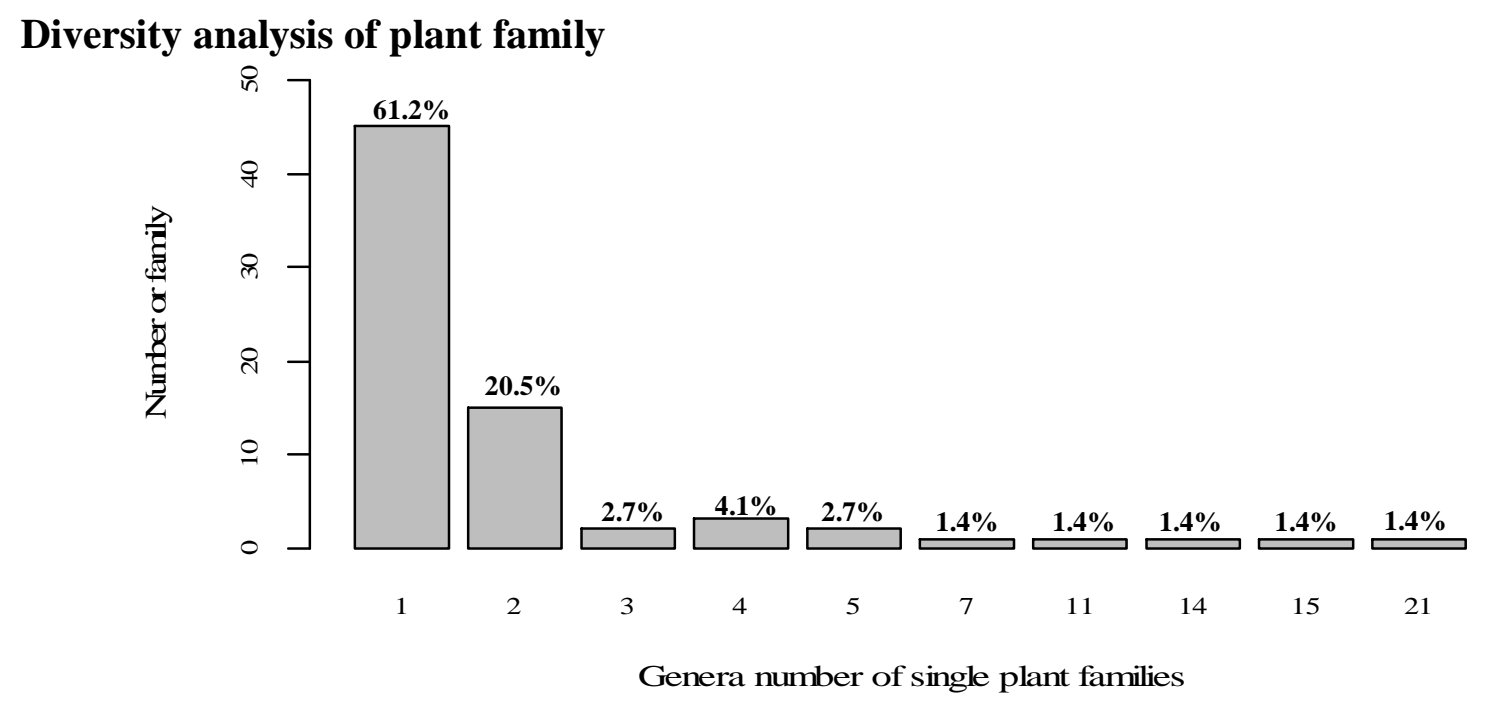

Fig 1.Wetland Park's composition of genera of plant families

There are 73 families of seed plants of Tianjin lingang Urban Ecological Wetland Park(Fig.1), some of them are highly evolved,such as Compositae,Gramineae;some angiosperms like Saxifragaceae are in a differentiated position. The number of genera in different family has great disparity.There are 5 family contained more than 5 generas, these are Compositae(21 generas), Gramineae(15), Rosaceae (14), Leguminosae (11), Oleaceae (7), their propotion are all 1.37\%; while, monotypic genera has 47 familis which account for $64.38 \%$, and two generas have 15 families which have a share of $20.55 \%$. These kid of family had larger proportion in the total which take the subdomination role in plant flora.

\section{Diversity analysis of plant genera}

There are 171 generas of seed plants of Tianjin lingang Urban Ecological Wetland Park(Fig.2), some generas are highly evolved contained many herb generas,such as Compositae, Cyperaceae,there also has lower level of evolution plants from ancient types,Compositae's Heteropappus is one of the few woody generas.It showed that Lingang ecological wetland species 
of vegetation are abundant and weren't dominanted by a single dominant specie(Fig.2).Monotypic genera had a total of 137 generas with absolute advantage, a total of 137 genus, $80.12 \%$ of the total genera number.Six generas contained more than 5 species, Chenopodiuma and Salix has 8 species, occupying 1.2\%; Sophora(7 species) account for 06\%;Sabina,Prunus and Malus are all woody plants occupying 5 species.

Chenopodium and Artemisia are typical wetland weed communities have a wide distribution in Tianjin, Chenopodium is mainly distributed on the border of wetland and land, associated with Phragmites australis, Lythrum salicaria and so on.Artemisia is always distributed in some arid areas around wetlands.Statistics shows that differentiation of Tianjin local genus is quite significant, medium and small generas are abundant,a few large genera are high developed mostly manual transplanting plants, the influence from artificial intervention is more obvious.

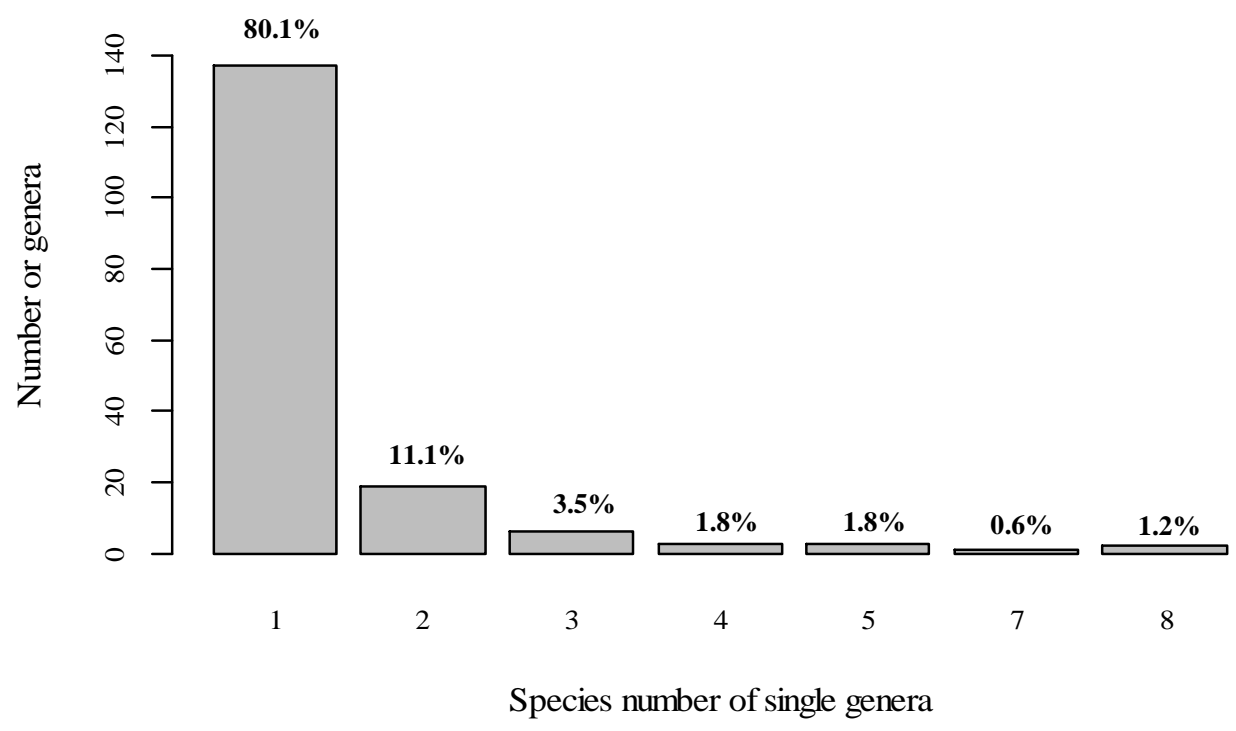

Fig 2. Wetland Park's composition of species of plant genera

\section{Growth-forms of vegetation type}

The growth-forms of vegetation type dominated by arbor, shrub, vine, perennial grasses, annuals, biennial and perennial herbs, a total of 246 species. Of which, herb with 122 species account for $49.6 \%$ of the total species at most, arbor second was 78 species and account for $31.7 \%$, shrub owns 41 species and account for 16.7\%; vine and perennial grasses at least was 4 and 1 specie respectively. A ratio of wild plant species was $31.3 \%$ with 77 species,among them, there are 71 herbs,5 shrubs and 1 vines,the only one vines is Metaplexis japonica;cultivated species(169) account for $68.7 \%$.In addition, over $90 \%$ wild species were introduced in herbs, over $45 \%$ cultivted species were introduced in anbors, of them, the number of trees was at most, herbs second and shrubs at least in the life-forms of vegetation,the proportion was trees $(46.8 \%)$, herbs $(30.2 \%)$ and shrubs $(21.3 \%)$ in order. 


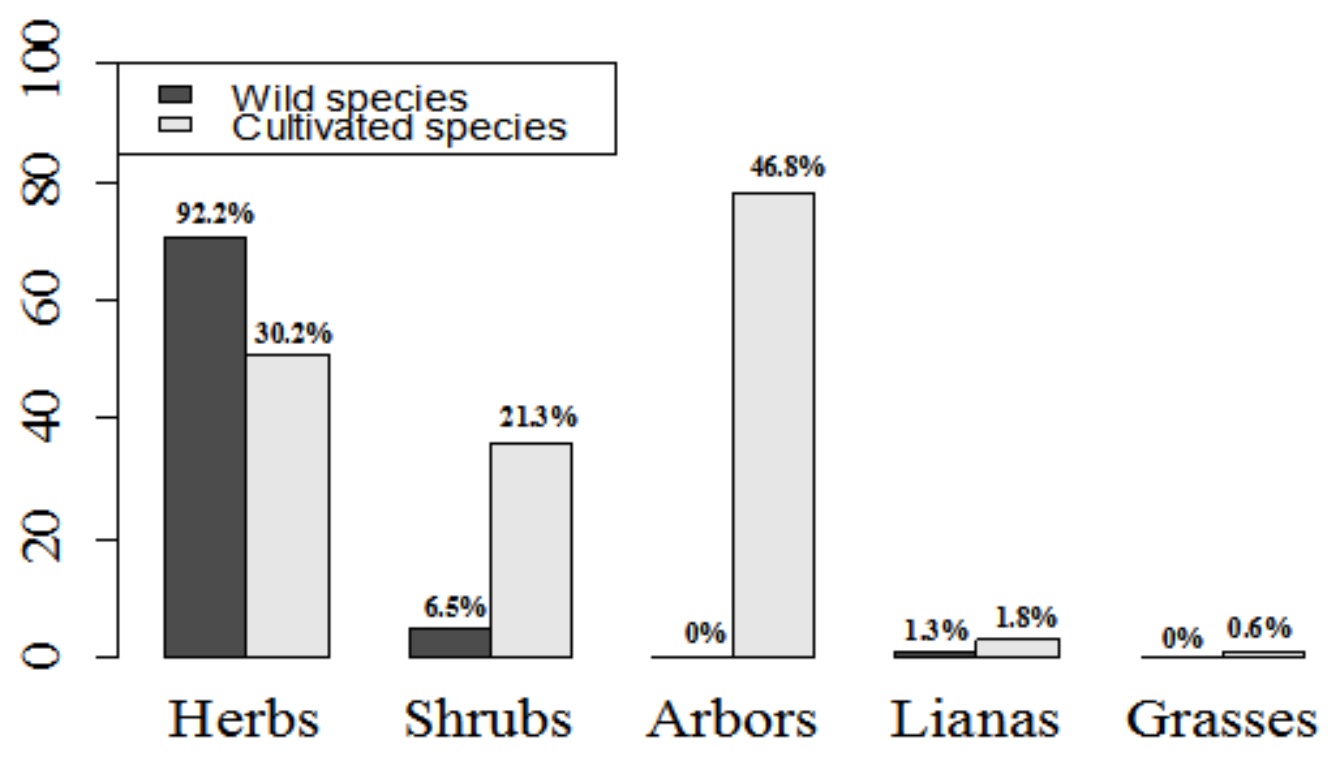

Fig 3. Patterns of plant flora of Wetland Park

\section{Analysis of floristic geographical elements}

According to Wu Zhengyi (1991) ${ }^{[3]}$ classified the areal-types of Chinese genera of seed plants, the distribution of the seed plants in the study area could be divided into 15 geographical elements types and 9 sub-type (Table 1). Floristic composition varied within the study area, which is widely distributed.North Temperate type and the Pan-tropic are the main parts of the floristic geographical elements owning larger proportion of distribution respectively account for $27.71 \%$ and $15.1 \%$ of total (Fig 4).Among them, the pan-tropical distribution is at the one

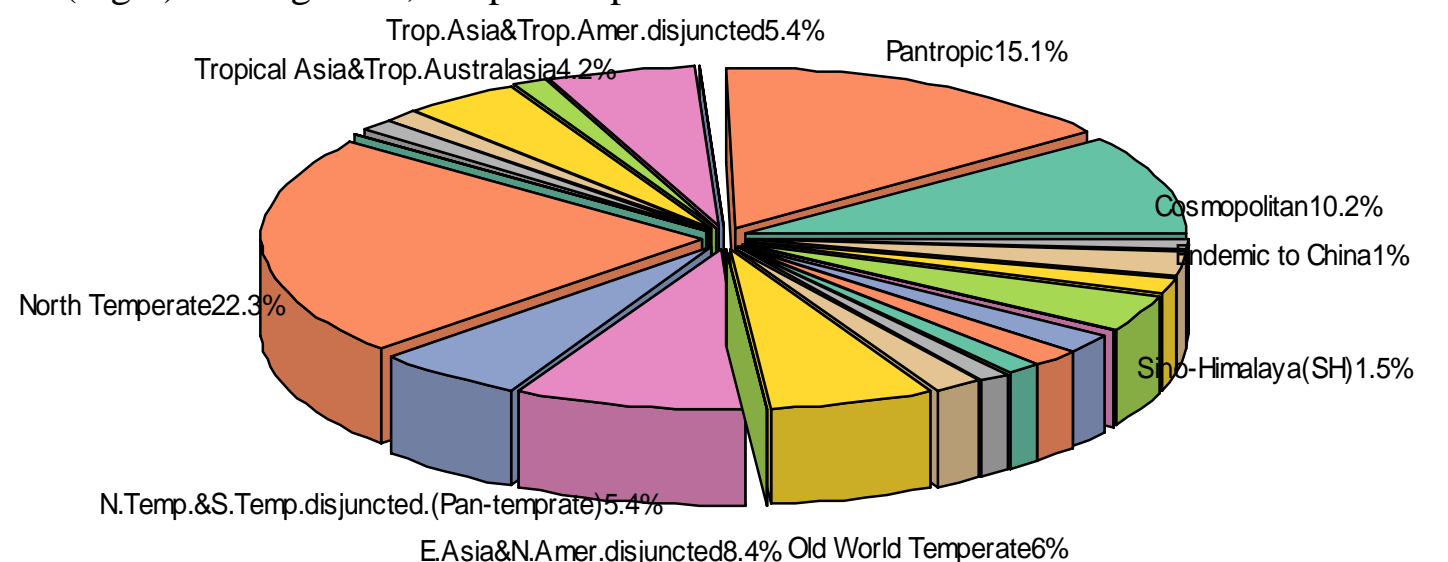

Fig 4. Genera numbers 's areal-types and variants of plants in the study area

or a plurality of distribution center widely distributed around the World tropical range, many generas are also distributed in the temperate zone, port wetland in the pan tropical plant distribution mostly belongs to the herbs and lianas,most gereras of the pan tropical were herbs and vines in Lingang ecological wetland prak,such as Portulaca, Imperata,Setaria and Diospyros,of which is relatively common in Tianjin.Addition,Chinese unique species in research district within also has distribution, for Eucommia and Ginkgo a total of $1 \%$ of the total number of genera. World distribution of herb species serve to complement it and accounted for $13.86 \%$, which monotypic species has 11 species, by accounted for proportion for 37.93\%.Most plant species within the genus Chenopodium contains lots of wetland herbaceous species as dominant species in the study area; duckweed genera,genus Scirpus,Potamogeton,Atriplex,Suaeda are also typical vegetation types in the region. 
Table 1. Generic areal-types and variants of seed plants in the study area

\begin{tabular}{|c|c|c|c|c|c|c|c|c|c|}
\hline $\begin{array}{l}\text { Areal-type \& } \\
\text { variants }\end{array}$ & Genera & Species & $\begin{array}{l}\text { Genera's } \\
\text { proportion }\end{array}$ & $\begin{array}{l}\text { Species' } \\
\text { proportion }\end{array}$ & $\begin{array}{l}\text { Areal-type \& } \\
\text { variants }\end{array}$ & Genera & Species & $\begin{array}{l}\text { Genera's } \\
\text { proportion }\end{array}$ & $\begin{array}{l}\text { Species' } \\
\text { proportion }\end{array}$ \\
\hline 1.Cosmopolitan & 17 & 28 & $10.24 \%$ & $13.86 \%$ & $\begin{array}{l}\text { 9.1.E.Asia and } \\
\text { Mexico } \\
\text { disjuncted. }\end{array}$ & 1 & 1 & $0.60 \%$ & $0.50 \%$ \\
\hline 2. Pantropic & 25 & 31 & $15.06 \%$ & $15.35 \%$ & $\begin{array}{l}\text { 10.Old World } \\
\text { Temperate }\end{array}$ & 10 & 13 & $6.02 \%$ & $6.44 \%$ \\
\hline $\begin{array}{l}\text { 2.2.Trop.Asia,Afri } \\
\text { ca \& C.to } \\
\text { S.Amer.disjunct } \\
\text { ed. }\end{array}$ & & 1 & $0.60 \%$ & $0.50 \%$ & $\begin{array}{l}\text { 10.1.Mediterranea. } \\
\text { W.Asia(orC.Asi } \\
\text { a)\&E.Asia } \\
\text { disjuncted. }\end{array}$ & 3 & 8 & $1.81 \%$ & $3.96 \%$ \\
\hline $\begin{array}{l}\text { 3.Trop. Asia \&T } \\
\text { rop.Amer. } \\
\text { disjuncted }\end{array}$ & 9 & 13 & $5.42 \%$ & $6.44 \%$ & $\begin{array}{l}\text { 10.2. Mediterranea } \\
\text { \&Himalaya } \\
\text { disjuncted. }\end{array}$ & 2 & 3 & $1.20 \%$ & $1.49 \%$ \\
\hline $\begin{array}{l}\text { 4.Old World } \\
\text { Tropics }\end{array}$ & 2 & 2 & $1.20 \%$ & $0.99 \%$ & $\begin{array}{l}\text { 10.3.Eurasia \&S. } \\
\text { Africa(Some- } \\
\text { times also } \\
\text { Australasia) } \\
\text { disjuncted. }\end{array}$ & 2 & 2 & $1.20 \%$ & $0.99 \%$ \\
\hline \multicolumn{10}{|l|}{ 5.Tropical Asia } \\
\hline $\begin{array}{l}\text { \&T rop. } \\
\text { Australasia }\end{array}$ & 7 & 9 & $4.22 \%$ & $4.46 \%$ & 11.Temp. Asia & 3 & 3 & $1.81 \%$ & $1.49 \%$ \\
\hline $\begin{array}{l}\text { 6.Trop. Asia to } \\
\text { Trop. Africa }\end{array}$ & 2 & 3 & $1.20 \%$ & $1.49 \%$ & $\begin{array}{l}\text { 12. Mediterranea, } \mathrm{W} \\
\text {. Asia to c. Asia }\end{array}$ & 3 & 3 & $1.81 \%$ & $1.49 \%$ \\
\hline $\begin{array}{l}\text { 7.Trop. Asia (Indo } \\
\text { Malesia) }\end{array}$ & 2 & 2 & $1.20 \%$ & $0.99 \%$ & 13.C. Asia & 1 & 1 & $0.60 \%$ & $0.50 \%$ \\
\hline $\begin{array}{l}\text { 7.3.Burma, Thailan } \\
\text { d to SW. } \\
\text { China. }\end{array}$ & 1 & 1 & $0.60 \%$ & $0.50 \%$ & 14.E. Asia & 6 & 6 & $3.61 \%$ & $2.97 \%$ \\
\hline 8.North Temperate & e 37 & 69 & $22.29 \%$ & $34.16 \%$ & $\begin{array}{l}\text { 14.1Sino-Himalaya } \\
\quad(\mathrm{SH})\end{array}$ & 3 & 3 & $1.81 \%$ & $1.49 \%$ \\
\hline $\begin{array}{l}\text { 8.4.N.Temp.\&S.Te } \\
\text { mp.disjuncted.(" } \\
\text { Pan-temprate") }\end{array}$ & & 11 & $5.42 \%$ & $5.45 \%$ & $\begin{array}{l}\text { 14.2.Sino-Japan } \\
\text { (SJ) }\end{array}$ & 4 & 9 & $2.41 \%$ & $4.46 \%$ \\
\hline $\begin{array}{l}\text { 9.E.Asia\&N.Amer } \\
\text { disjuncted }\end{array}$ & r. 14 & 13 & $8.43 \%$ & $6.44 \%$ & $\begin{array}{l}\text { 15.Endemic to } \\
\text { China }\end{array}$ & 2 & 2 & $1.20 \%$ & $0.99 \%$ \\
\hline
\end{tabular}

\section{Conclusion}

(1)Lingang urban ecological wetland park has a complicated geographical environment with a variety of plants. There are 246 speices and accounted for $18.1 \%$ of total number of species of vascular plants in Tianjin(1359), of which is represented by the species of Rosaceae, Compositae and Gramineae.There are other distinguishing species such as Ash tree, the composition of plants of Lingang wetland park is representative in the North China.

(2)Cultivated species account for a large proportion(68.7\%), there are less wild species, which are mostly herbaceous plants.

(3)Diverse floristic composition distribution types covered the types of 15 geographical elements types and 9 sub-type of China. Which,Temperate ingredients were divided the for 2 geographic type components accounted for absolute advantage( $27.72 \%)$,

temperate sex components total 46 is, was placed under the for 2 a geographic type components, accounted for total is number of $27.72 \%$. The more regional monotypic families and generas fully reflected the vulnerability of regional plant flora and the necessity of strengthening the wetland conservation.

(4)Endemic families and genera of seed plants are still insufficient.Only two Chinese unique generas were found in Lingang urban ecological wetland and flora's personality is not obvious. 


\section{References}

[1] Xiu C,Ouyang Z Y,Zheng H 2014 Flora analysis of riparian vegetation in Yongding-Haihe river system, China. J. Acta Ecologica Sinica, 34(6):1535-1547

[2] Wang H S 1992 Floristic Geography(Beijing:Science) p1-180

[3] Wu Z Y 1991 The areal-types of Chinese genera of seed plants J. Acta Botanica Yunnancia ,13(Suppl.IV):1-139

[4] Li M L,Zhang T M,Hu D,Chen W 2006Flora of higher plant in wetland of Beijing area $J$. Wetland Science,4(3):219-226

[5] Shangguan T L,Zhang F,Zhang L S,Song B W 2000 Study on dibersity of vascular plant of wetland in Shanxi J.Bulletin of Botanical Research,20(3):275-281

[6] Wang C,Liu Q R 2004 Study on the flora of vascular plants of wetland in Beijing J.Journal of Wuhan Botanical Research,22(5):406-411

[7] Tie W,Zhi long S,Ye D,Hui F,Yao T 2014 Design and Operation of Urban Ecological Wetland Park in Lingang Economic Zone of Tianjin City J. China Water\&Wastewater, 30(14):42-45

[8] Qi Y,Li H Y 2015 Typical ecological restoration cases of Jing-jin-ji(Tianjin:Science and technology)p127-138 